\title{
Karyotypes of eight species of Leptodactylus (Anura, Leptodactylidae) with a description of a new karyotype for the genus
}

\author{
Renata Cecília Amaro-Ghilardi, ${ }^{1,4}$, Gabriel Skuk², Rafael O. de Sá ${ }^{3}$, Miguel Trefaut \\ Rodrigues $^{4}$, and Yatiyo Yonenaga-Yassuda ${ }^{1}$ \\ 1 Departamento de Genética e Biologia Evolutiva, Instituto de Biociências, Universidade de São Paulo, CP 11.461, \\ 05422-970, São Paulo, SP, Brazil. E-mail: amarorc@usp.br. \\ 2 Departamento de Zoologia, Centro de Ciências Biológicas, Universidade Federal de Alagoas, AL, Brazil. \\ 3 Department of Biology, University of Richmond, Richmond, Virginia, 23173, USA. \\ ${ }^{4}$ Departamento de Zoologia, Instituto de Biociências, Universidade de São Paulo, São Paulo, SP, Brazil.
}

\begin{abstract}
Karyotypes of eight species of Leptodactylus (Anura, Leptodactylidae) with a description of a new karyotype for the genus. Eight species of the Neotropical genus Leptodactylus were karyologically studied: seven of them (L. gracilis, L. mystacinus, L. petersii, L. pustulatus, L. macrosternum, L. ocellatus, L. labyrinthicus) presented $2 \mathrm{n}=22$ and $L$. silvanimbus showed a distinctive karyotype with $2 \mathrm{n}=24$. Nucleolar organizer regions (Ag-NORs) were detected in two different pairs of chromosomes: pair 4 at the proximal region of the long arm of one individual of $L$. mystacinus from São Paulo state and of L. petersii; and pair 8 of all other species (located terminally at the short arm of L. silvanimbus, L. ocellatus, L. macrosternum, L. pustulatus, and $L$. labyrinthicus; interstitially at the short arm in L. gracilis; and at the long arm in $L$. mystacinus from Mato Grosso state). The diploid number reported here for $L$. silvanimbus shared with Scythrophrys and Paratelmatobius could represent the ancestral chromosome number for Leptodactylus (sensu Frost et al. 2006); in this case the $2 n=22$ karyotypes would then represent the derivative condition for the genus. Nevertheless, the distinctive karyotype of $L$. silvanimbus lead us to preclude a final decision on its relationships. Additional studies including morphological and molecular approaches are needed in order to clarify the phylogenetic position of L. silvanimbus.
\end{abstract}

Keywords: Anura, Leptodactylidae, Leptodactylus, Leptodactylus silvanimbus, karyotypes, Ag-NORs.

\section{Introduction}

The genus Leptodactylus is distributed from southern Texas throughout lowland $(<1800 \mathrm{~m})$

Received 6 April 2006.

Accepted 14 November 2006.

Distributed December 2006.
Mexico, Central America, portions of the Greater and Lesser Antilles, and in South America on both sides of the Andes to Peru on the west and Argentina on the east. As conceived until recently (Frost 2004), about 64 species arranged in four traditionally recognized species groups were recognized for the genus (Heyer 
1969): fuscus, melanonotus, ocellatus, and pentadactylus. Recently, de Sá et al. (2005) proposed that the monotypic genus Vanzolinius should be a synonym of Leptodactylus, based on molecular and morphological data. This concept of Leptodactylus changed again more recently following a comprehensive molecular and morphological study on the relationships among major groups of amphibians (Frost et al. 2006). In this paper, Vanzolinius is deeply imbedded within Leptodactylus supporting its synonymy with Leptodactylus, Adenomera is placed in the synonymy of Lithodytes, and Lithodytes is placed as a subgenus Leptodactylus. The same paper restricted the content of Leptodactylidae to Leptodactylus, Edalorhina, Engystomops, Eupemphix, Hidrolaetare, Paratelmatobius, Physalaemus, Pleurodema, Pseudopaludicola, Scythrophrys, and Somuncuria. A more recent publication (Grant et al. 2006), based on the same molecular data used by Frost et al. (2006) but on a different taxonomic sampling, restricted the leptodactylids to Leptodactylus, Hidrolaetare, Paratelmatobius, and Scythrophrys.

As frog systematics is undergoing a period of active revision and change affecting the contents of families and genera, we prefer to take a conservative approach and follow the "traditional” concept of Leptodactylus to present our data.

The karyotypes of 25 species of Leptodactylus (sensu Frost 2004) have been described (Appendix I); most of them were exclusively based on conventional staining and description of number and chromosome morphology. Leptodactylus species have 22 chromosomes with slight differences in morphology among the species (King 1990, Kuramoto 1990, AmaroGhilardi et al. 2004). Studies including differential staining showed species-specific Cbanding patterns in Leptodactylus gracilis gracilis, L. gracilis delattini, L. knudseni, L. labyrinthicus, L. notoaktites, L. pentadactylus, L. plaumanni, and L. podicipinus; furthermore differences in the distribution of constitutive heterochromatin among populations of $L$. fuscus, L. mystacinus, and L. ocellatus were also observed (Silva et al. 2000, 2004, 2006, Baldo 2002, Amaro-Ghilardi et al. 2004). Nucleolar organizer regions (NORs) were detected in the short arm of pair 8 of all species studied, except for L. latinasus and L. podicipinus, which showed NORs in the long arm of pair 8 (Silva et al. 2000, Baldo 2002); and for L. mystacinus, which presented a polimorphism of NORs: individuals from Misiones, Argentina, showed NORs in the interstitial region of the short arm of pair 4 and specimens from São Paulo state, Brazil, presented interindividual variation of NORs in both pairs 4 and 8 (Baldo 2002, Silva et al. 2006).

Leptodactylus silvanimbus is a species with an interesting distribution, occurring in cloud forest and moderate elevation pine forest habitats in extreme southwestern Honduras. The species is known from three localities at moderate and intermediate elevations (1470$2000 \mathrm{~m}$ ) along the Continental Divide of the Cordilleras de Celaque and del Merendón in Departamento Ototepeque, Honduras (Heyer et al. 2002). Leptodactylus silvanimbus was not clearly allocated to any previously defined species group of Leptodactylus in its original description. Subsequently, L. silvanimbus was considered a member of the melanonotus group (Mc Craine et al. 1986, Heyer et al. 1996), or as a part of a melanonotus-ocellatus clade (Larson and de Sá 1998). Molecular data analyses of $12 \mathrm{~S}$ and $16 \mathrm{~S}$ mitochondrial genes indicated that L. silvanimbus does not show a clear relationship with the "traditional" species groups of Leptodactylus, however these data suggested that $L$. silvanimbus may have a basal position within Leptodactylus (Heyer et al. 2005, de Sá et al. 2005).

Herein we describe the karyotype of $L$. silvanimbus, which presents a diploid number not reported to any species allocated in the former genus Leptodactylus. The karyotype of L. silvanimbus is compared to the karyotypes of L. gracilis, L. mystacinus (fuscus group), $L$. petersii, L. pustulatus (melanonotus group), $L$. 

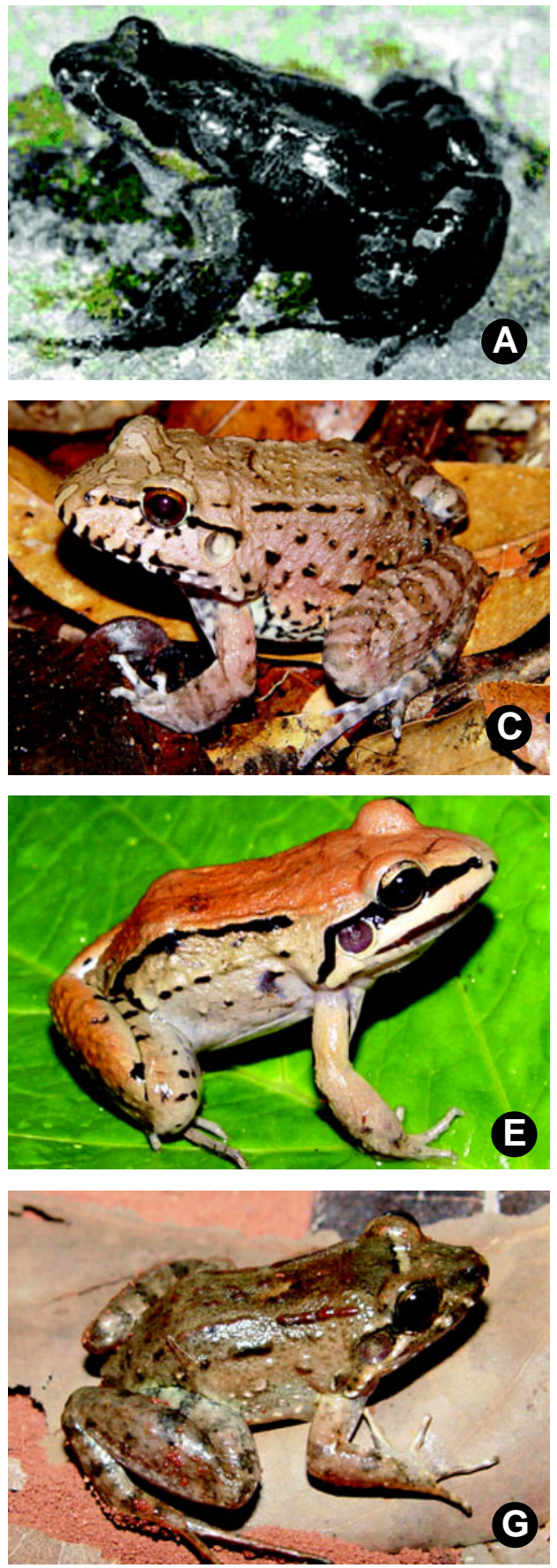
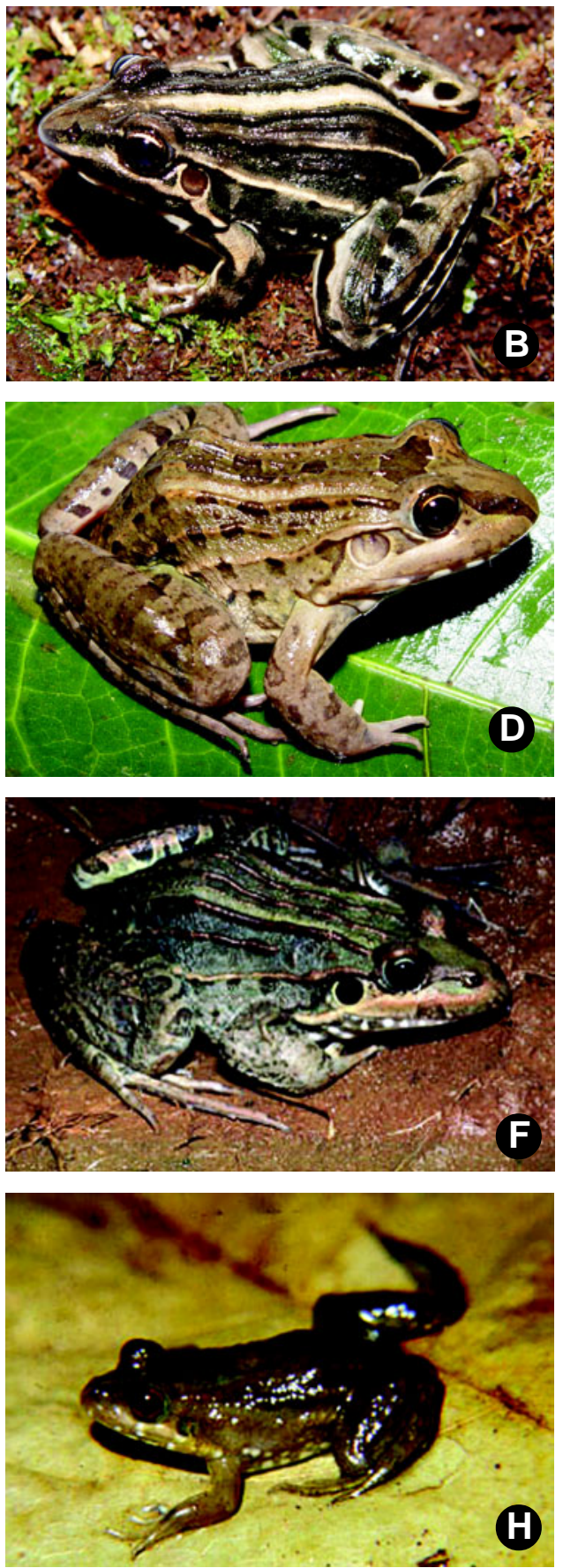

Figure 1 - (A) Leptodactylus silvanimbus (from Heyer et al. 2002), (B) L. gracilis, (C) L. labyrinthicus, (D) L. macrosternum, (E) L. mystacinus, (F) L. ocellatus, (G) L. petersii, (H) L. pustulatus. Photos: Felipe F. Curcio (B, C, D, E, G), Gabriel Skuk (F) and Vinicius Xavier (H). 
macrosternum, L. ocellatus (ocellatus group), and L. labyrinthicus (pentadactylus group). The karyotypes of $L$. petersii, L. pustulatus, $L$. macrosternum, and L. silvanimbus are here reported for the first time and those of $L$. gracilis, L. mystacinus, L. ocellatus, and $L$. labyrinthicus are reported from new localities. Finally we compare the new karyological data reported with those know for Adenomera, Lithodytes, and Vanzolinius, as well as to other related Leptodactylidae.

\section{Material and Methods}

Cytogenetic analyses were carried out on 17 specimens of Leptodactylus: L. gracilis, $L$. mystacinus (fuscus group), L. petersii, L. pustulatus (melanonotus group), L. macrosternum, L. ocellatus (ocellatus group), L. labyrinthicus (pentadactylus group), and $L$. silvanimbus (Figure 1). Localities, number and sex of the individuals are provided in Appendix II and Figure 2.

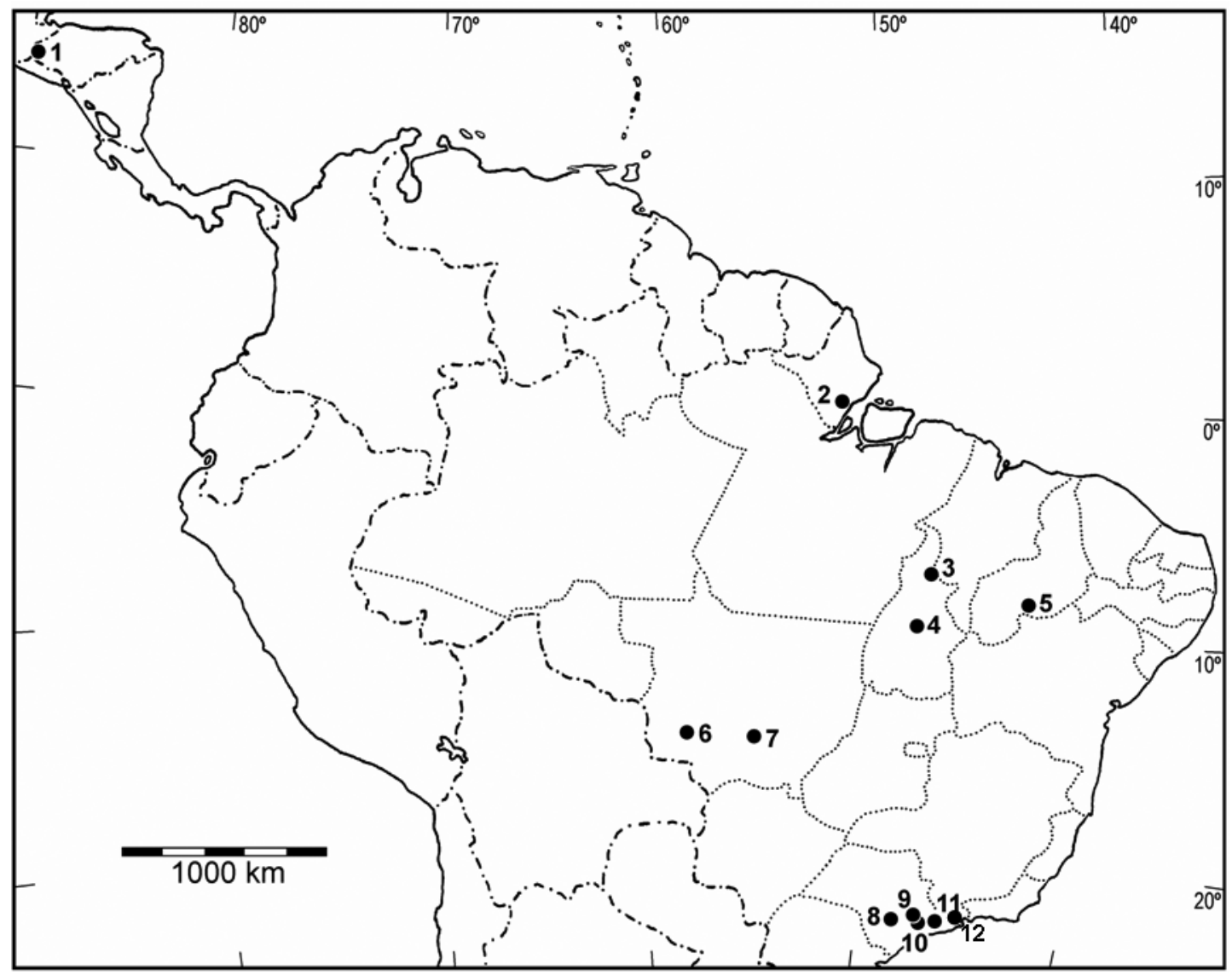

Figure 2 - Localities of Leptodactylus analyzed in this paper. (1) Ocotepeque, Belén Gualcho, Honduras - L. silvanimbus; (2) Igarapé Camaipi, AP - L. petersii; (3) Palmeirante, TO - L. macrosternum and L. pustulatus; (4) Palmas, TO - L. macrosternum; (5). Caracol, PI - L. labyrinthicus; (6) Jauru, MT - L. mystacinus; (7) Chapada dos Guimarães, MT - L. mystacinus; (8) Buri, SP - L. ocellatus; (9) Piedade, SP - L. ocellatus; (10) Juquitiba, SP - L. ocellatus; (11) São Bernardo do Campo, SP - L. gracilis; (12) Jambeiro, SP - L. mystacinus. 
Mitotic metaphases were obtained either from bone marrow, liver, spleen or intestine after in vivo colchicine treatment according to conventional protocols (Bogart 1973b, Schmid 1978) or from fibroblast culture (AmaroGhilardi et al. 2004). Chromosome studies were performed after Giemsa and Ag-NOR staining (Howell and Black 1980).

\section{Results}

The karyotype of $L$. silvanimbus consists of 24 chromosomes, with pairs 1 to 6 submetacentrics and pairs 7 to 12 metacentrics (Figure 3A). All other Leptodactylus have karyotypes with $2 \mathrm{n}=22$. In $L$. petersii pairs 1 to 5 are submetacentrics and pairs 6 to 11 are metacentrics (Figure 3B). In L. pustulatus pairs 1 to 4 and pair 7 are submetacentrics; pairs 5, 6, and 8 to 11 are metacentrics (Figure 3C). In $L$. labyrinthicus and L. ocellatus pairs 1, 5, 6, 9, 10 and 11 are metacentrics and pairs 2, 3, 4, 7 and 8 are submetacentrics (Figure 3D and 4A). The karyotype of $L$. macrosternum is similar to that of L. labyrinthicus and $L$. ocellatus, except for pair 8 that is metacentric instead of submetacentric (Figure 4B). In L. mystacinus pairs 1 to 4 and 7 and 8 are submetacentrics and pairs 5, 6, 9, 10 and 11 are metacentrics (Figure 4C). Leptodactylus gracilis has a karyotype similar to L. mystacinus, except for pair 8 that is metacentric (Figure 4D).

Presence of a secondary constriction was detected in different positions of pair 8: at the terminal region of the short arm of $L$. labyrinthicus and L. ocellatus (Figure 3D and Figure 4A); at the interstitial region of the short arm of L. gracilis (Figure 4D) and at interstitial portion of the long arm of L. mystacinus from Mato Grosso State (Figure 4C).

Nucleolar organizer regions (Ag-NORs) were detected in two chromosome pairs: pair 4 at the proximal region of the long arm of in $L$. petersii (Figure 5B) and L. mystacinus from Jambeiro, São Paulo state (Figure 6C) and pair 8 of the other species, including individuals of $L$. mystacinus from Chapada dos Guimarães e Jauru, Mato Grosso state (Figures 5A-C, 6). In L. silvanimbus, L. ocellatus, L. macrosternum, L. pustulatus, and L. labyrinthicus, Ag-NORs were detected at the terminal region of the short arm of pair 8 (Figures 5A-C, 6A,B) whereas in L. gracilis they were found interstitially at the short arm of this pair (Figure 6D). Leptodactylus mystacinus showed Ag-NORs interstitially at the long arm of pair 8 in the individuals from Mato Grosso state (Figure 6C).

\section{Discussion}

Heretofore all species of Leptodactylus (sensu Frost 2004) cytogenetically studied had $2 n=22$. Karyotypes presented here for $L$. gracilis, L. labyrinthicus, $L$. mystacinus, and $L$. ocellatus are similar to those previously reported (Barbieri 1950, Saez and Brum 1960, Bianchi and Molina 1967, Beçak 1968, BrumZorrilla and Saez 1968, Denaro 1972, Barrio 1973, Bianchi et al. 1973, Bogart 1974, Kasahara et al. 1998, Silva et al. 2000, 2004, 2006, Baldo 2002, Amaro-Ghilardi et al. 2004). Leptodactylus silvanimbus is unique among the species previously included in Leptodactylus showing a karyotype consisting of 24 chromosomes. Nevertheless this diploid number has been reported for Adenomera marmorata, a taxon now included in Leptodactylus. As Adenomera marmorata has six pairs of telocentric chromosomes (Bogart 1974), its karyotype shows striking differences when compared with that of $L$. silvanimbus which encompasses only biarmed chromosomes. In Adenomera andreae and A. hylaedactyla, another diploid number $(2 \mathrm{n}=26)$ was reported (Bogart 1970, 1973a; 1974). The karyotype of Lithodytes lineatus, another taxon included in Leptodactylus by Frost et al. (2006), are composed of 18 biarmed chromosomes (Bogart 1970) and Vanzolinius discodactylus has a $2 n=22$ karyotype very similar to the other Leptodactylus above referred (Heyer and Diment 1974). Results of Frost et al. (2006) and 


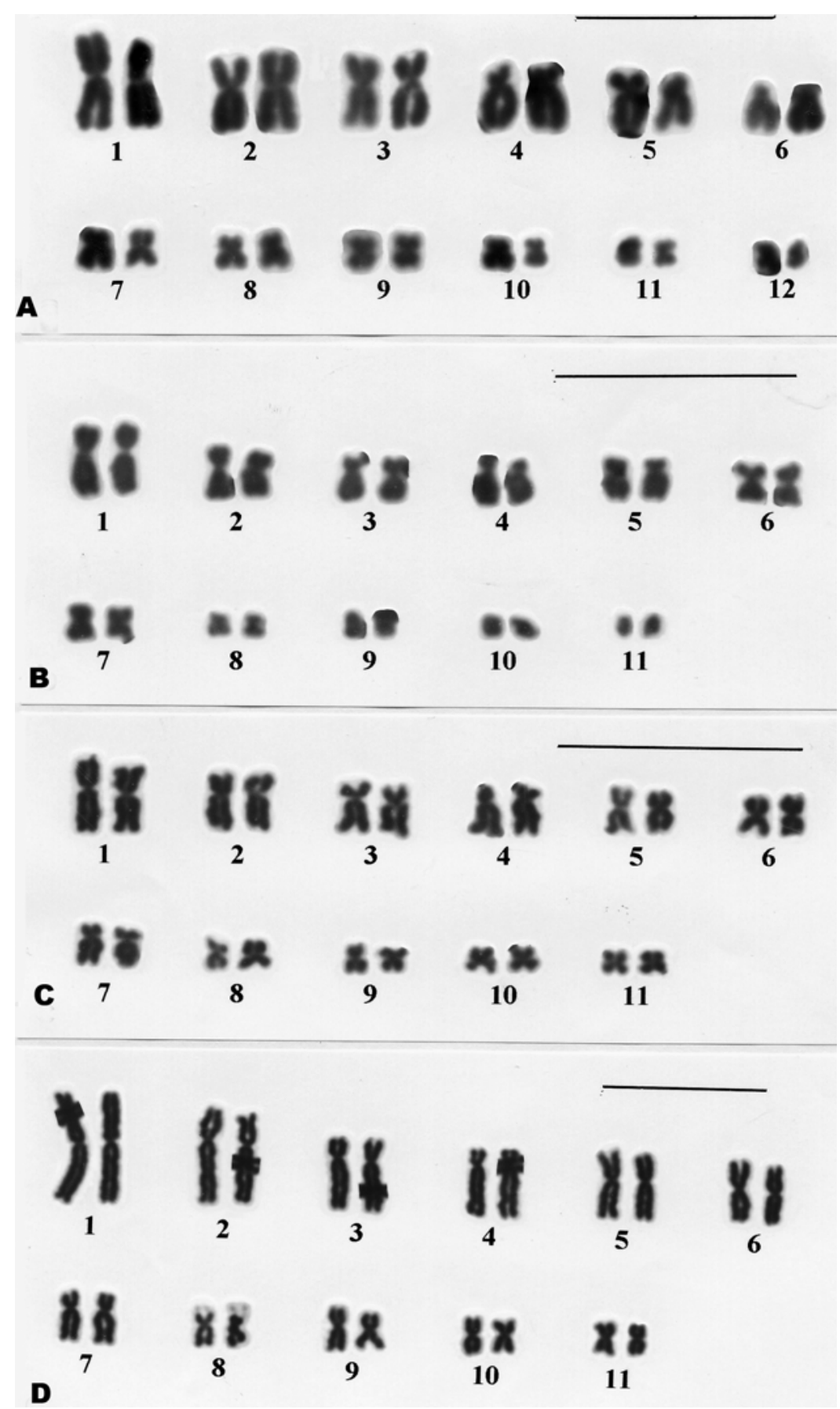

Figure 3 - Conventional stained karyotypes of Leptodactylus. (A) L. silvanimbus $(2 \mathrm{n}=24)$, (B) L. petersii ( $2 \mathrm{n}=22)$, (C) L. pustulatus $(2 \mathrm{n}=22)$, (D) L. labyrinthicus $(2 \mathrm{n}=22)$. Note the presence of terminal secondary constriction in the short arm of pair 8 of L. labyrinthicus (D). Bar=10 $\mu \mathrm{m}$. 


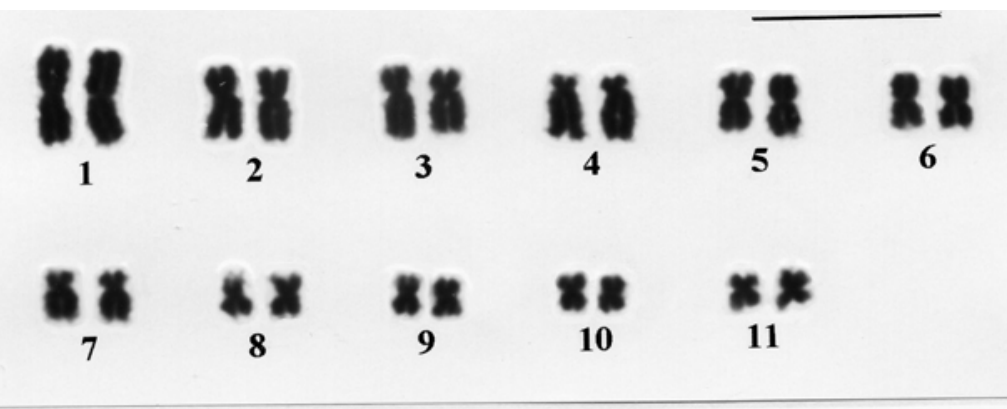

A

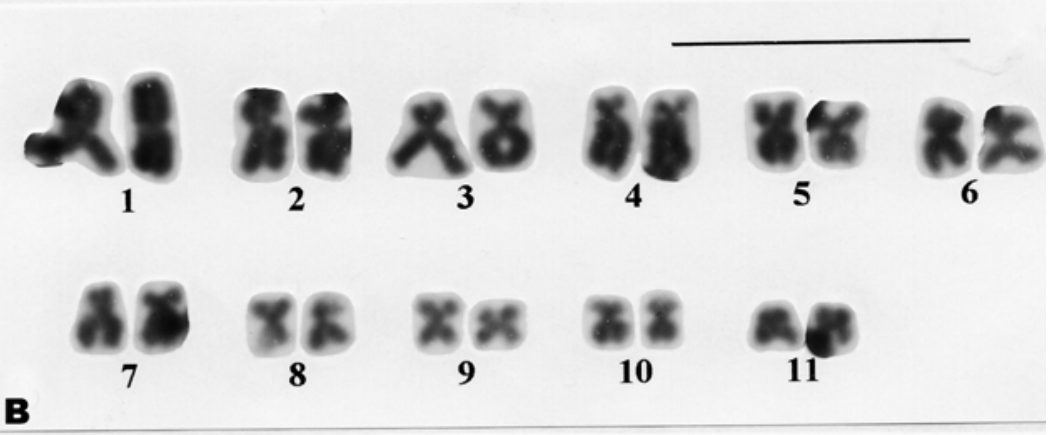

B
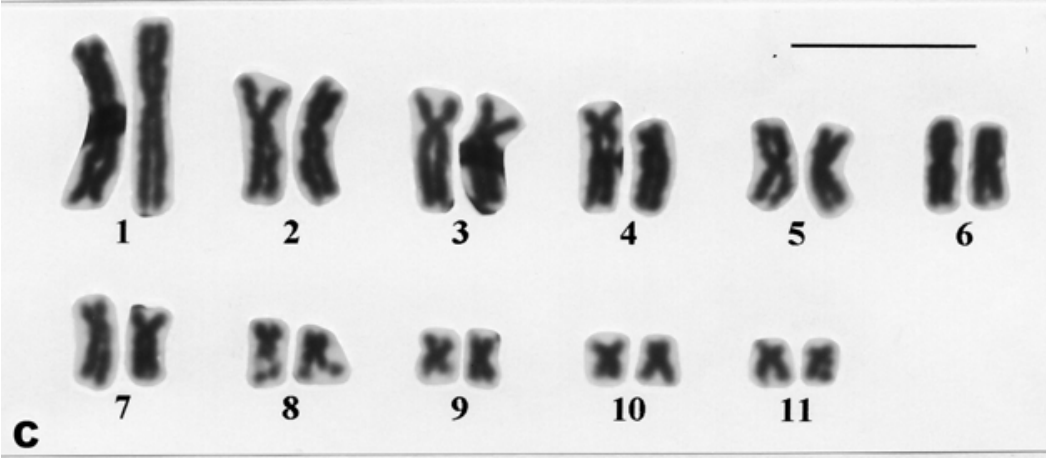

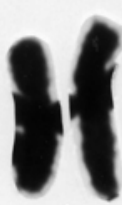

1

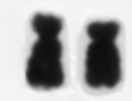

7

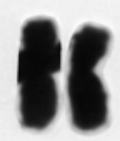

2

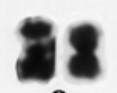

8

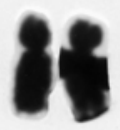

3

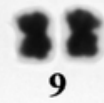

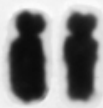

4

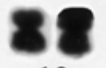

10

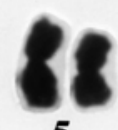

5
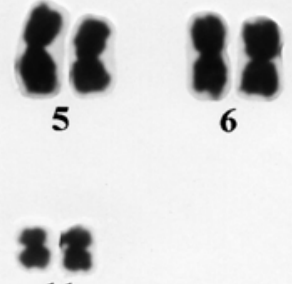

D

Figure 4 - Conventional stained karyotypes with 2n=22 of Leptodactylus. (A) L. ocellatus, (B) L. macrosternum, (C) L. mystacinus, (D) L. gracilis. Note the presence of terminal secondary constriction in one homologue of short arm of pair 8 of L. ocellatus (A), at interstitial portion of long arm of pair 8 of L. mystacinus (C) and in the interstitial region of short arm of pair 8 of L. gracilis (D). Bar $=10 \mu \mathrm{m}$. 
Amaro-Ghilardi et al.
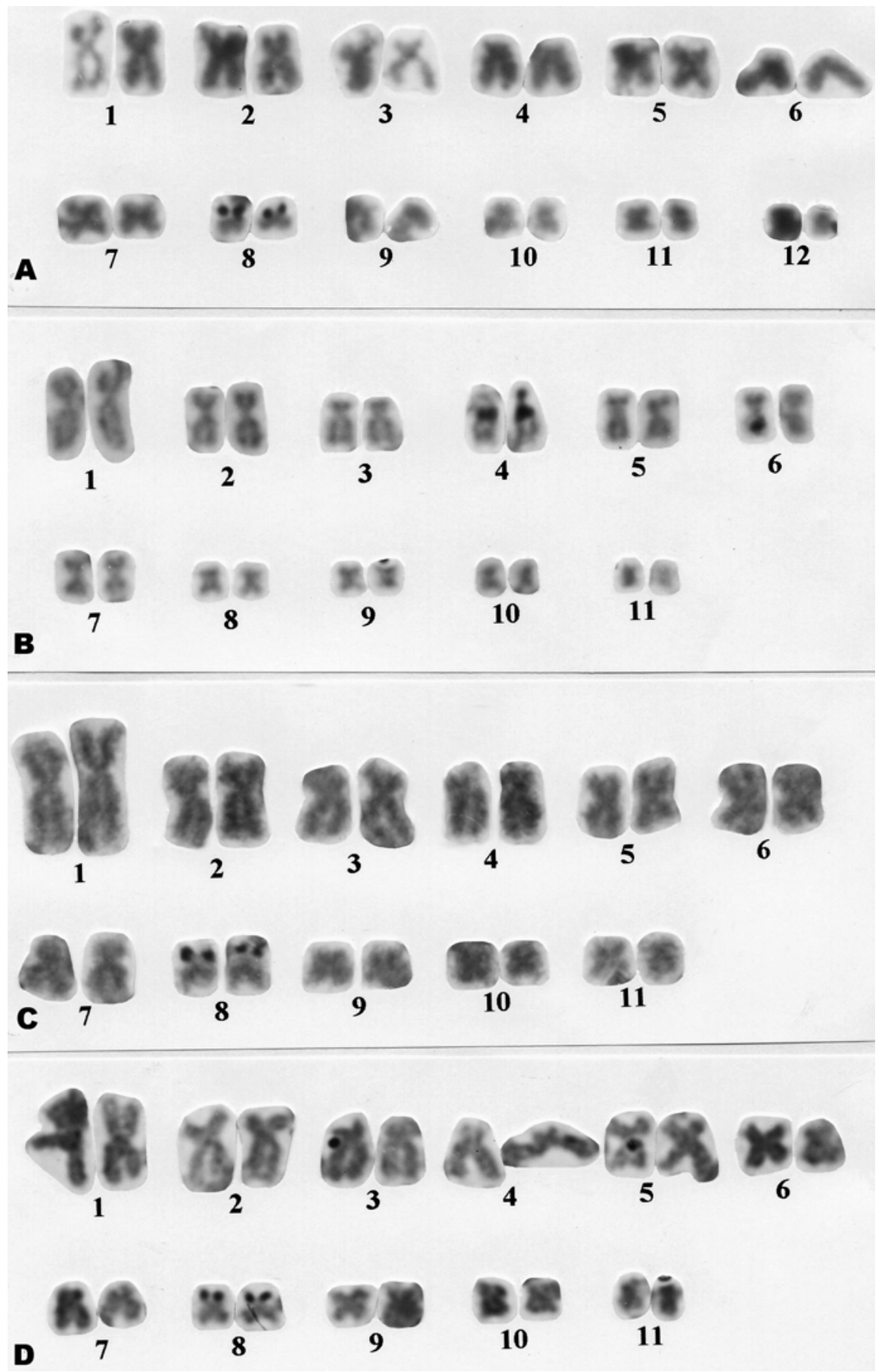

Figure 5 - Localization of NORs in Leptodactylus. (A) L. silvanimbus (pair 8), (B) L. petersii (pair 4), (C) L. pustulatus (pair 8), (D) L. labyrinthicus (pair 8). 


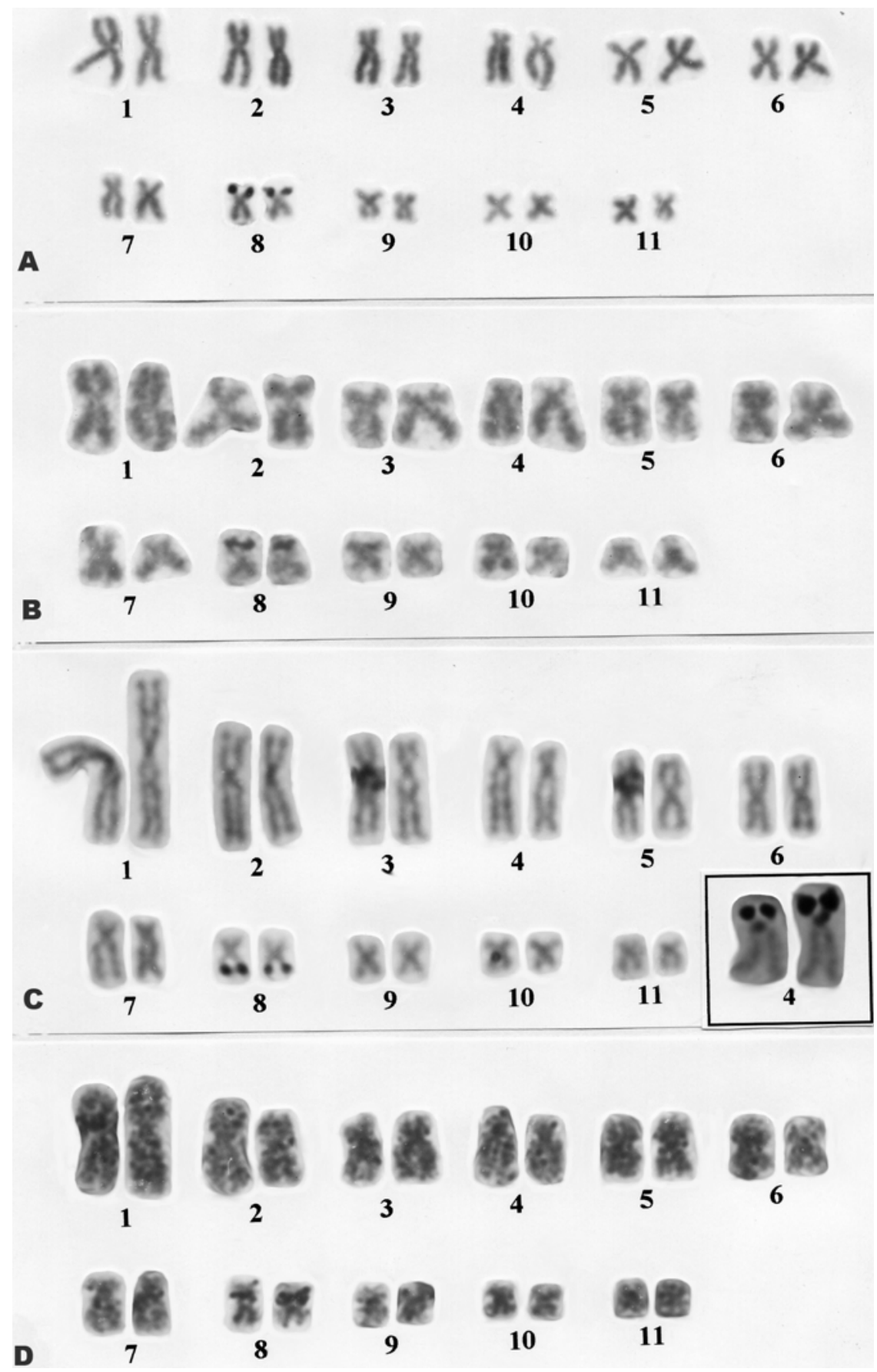

Figure 6 - Localization of NORs in Leptodactylus. (A) L. ocellatus (pair 8), (B) L. macrosternum (pair 8), (C) L. mystacinus [pair 8 to animals from Mato Grosso state and pair 4 (in the rectangle) to the individual from São Paulo state], (D) L. gracilis (pair 8). 
Grant et al. (2006) suggest that the clade including Paratelmatobius and Scythrophrys is the sister group of Leptodactylus, and in both genus karyotypes with 24 chromosomes were observed (De Lucca et al. 1974, Lourenço et al. 2000, 2001, 2003).

Taking a conservative approach to the contents of Leptodactylus (i.e., excluding Adenomera, Lithodytes, and Vanzolinius) the distinct diploid number of L silvanimbus could be interpreted according to two different hypotheses. Firstly, the $2 n=24$ karyotype in Leptodactylus could be derived from an ancestral karyotype with $2 n=22$, similar to that of other species of Leptodactylus (sensu Frost 2004), due to one event of chromosomal fission, followed by pericentric inversions in the pairs resulted from the fission, since only biarmed chromosomes are found in the $2 \mathrm{n}=24$ karyotype. Alternatively, the $2 n=24$ karyotype of $L$. silvanimbus could represent the ancestral diploid number for Leptodactylus and the $2 \mathrm{n}=22$ karyotypes would represent the derived condition in the genus. This second hypothesis would require a pericentric inversion followed by centric fusion. Phylogenetic reconstructions based on sequences of $12 \mathrm{~S}$ and $16 \mathrm{~S}$ mitochondrial genes was not able to solve the relationship of $L$. silvanimbus to other species of Leptodactylus; however it suggested that $L$. silvanimbus could have a basal position within the genus (de Sá et al. 2005, Heyer et al. 2005).

Considering the recent systematic changes proposed for Leptodactylus (Frost et al. 2006), we then have four diploid numbers in the genus: $2 n=18,2 n=22,2 n=24$, and $2 n=26$. Under this scenario, the sister group of Leptodactylus is the clade formed by Paratelmatobius-Scythrophrys both with $2 n=24$. Under this hypothesis, a diploid number of $2 \mathrm{n}=24$ would be considered the ancestral diploid number for Leptodactylus, currently only reported for L. silvanimbus, and the karyotypes of most Leptodactylus $(2 \mathrm{n}=22)$ and the subgenus Lithodytes $(2 \mathrm{n}=18$ and $2 \mathrm{n}=26)$ would represent derived conditions within Leptodactylus.
NORs were detected in two distinct sites: pair 4 in L. petersii and L. mystacinus from São Paulo state and pair 8 in L. gracilis, $L$. labyrinthicus, L. macrosternum, L. mystacinus from Mato Grosso state, L. pustulatus, L. ocellatus, and L. silvanimbus. Previously, AgNORs were described in pair 8 for many species of Leptodactylus and in pair 4 of L. mystacinus from Misiones, Argentina and from Descalvado e Mogi das Cruzes, São Paulo state (Silva et al. 2000, 2004, 2006, Baldo 2002, Amaro-Ghilardi et al. 2004). In the individuals of $L$. mystacinus from Descalvado analyzed by Silva et al. (2006) were also detected an inter- and intra-individual variation of number and location of NORs, in pairs 4 and 8 , and pair 4 were considered the main NOR-bearing pair. This intraspecific polymorphism in the position of Ag-NORs observed in L. mystacinus is uncommon among amphibians and was observed in few cases, both in inter- and intrapopulational levels, e.g. Hyla chrysoscelis and $H$. versicolor (Willey et al. 1989), Bufo terrestris (Foote et al. 1991), Rana japonica (Miura 1994), Agalychnis callidryas (Schmid et al. 1995), Hyla ebraccata (Kaiser et al. 1996), Physalaemus cuvieri (Silva et al. 1999), and Physalaemus petersi (Lourenço et al. 1998). Our sample of L. mystacinus is not sufficient to determine if all individuals from the populations studied show only one NOR-bearing pair; more individuals must be studied to confirm the fixation of only one pair of NORs in these populations.

Species with NORs in pair 8 showed differences in the exact location along the chromosome. In $L$. chaquensis, $L$. fuscus, $L$. knudseni, L. labyrinthicus, L. macrosternum, L. notoaktites, L. ocellatus, L. pentadactylus, $L$. pustulatus, and L. silvanimbus Ag-NORs were detected terminally at the short arm. In $L$. bufonius, $L$. elenae, $L$. fuscus from Argentina, $L$. gracilis, L. mystacinus from Cordoba, Salta and Tucuman, Argentina and L. plaumanni NORs were found interstitially at the short arm and in $L$. mystacinus from Mato Grosso state and $L$. podicipinus they were observed interstitially at 
the long arm of pair 8 (Silva et al. 2000, 2004, Baldo 2002, Amaro-Ghilardi et al. 2004, present study). These differences in the localization of NORs could be explained by inversion, in the cases of L. gracilis, L. mystacinus from Mato Grosso state, and L. podicipinus, or translocation or transposition, in the case of $L$. petersii and L. mystacinus from Misiones and São Paulo, as previously proposed by Silva et al. (2000), for example.

The cytogenetic data obtained for $L$. silvanimbus found a new chromosomal number, $2 \mathrm{n}=24$, for the genus Leptodactylus (sensu stricto, i.e., besides the subgenus Lithodytes). Furthermore, under the most recent molecular hypothesis, and heretofore the largest available analysis of amphibian relationships, this karyotype would represent the ancestral diploid number for the genus.

\section{Acknowledgements}

The authors are grateful to Dante Pavan, Felipe Curcio Franco, Karen Ventura, Marianna Dixo, Ricardo Arturo Guerra, Roberto do Val Vilela, Vanessa Kruth Verdade, Vinícius Xavier for collecting the specimens, and to Cyntia Esteves Lima and Glaciene Tomaz Oliveira for technical assistance. We are very grateful to Maria José de Jesus Silva for the valuable comments and suggestions on the manuscript. and to José Cassimiro da Silva Junior for the help with figures .

We thank Furnas Centrais Elétricas (FURNAS) for supporting the fieldwork in São Bernardo do Campo, Juquitiba, Buri and Piedade. We also thank Karen Ventura and Roberto do Val Vilela for some chromosome preparations. Grants for this study were provided by Conselho Nacional de Desenvolvimento Científico e Tecnológico (CNPq) and Fundação de Amparo à Pesquisa do Estado de São Paulo (FAPESP). We also acknowledge National Science Foundation support through award 0342918 to RdS and WRH. The specimens were collected under a permit from the Instituto Brasileiro do Meio Ambiente e Recursos Naturais Renováveis (IBAMA n 2001.003933/01, CGEN Processo $\mathrm{N}^{\circ}$ 02001.000504/2005-68).

\section{References}

Amaro-Ghilardi, R. C., M. T. Rodrigues and Y. YonenagaYassuda. 2004. Chromosomal studies after differential staining and fluorescence in situ hybridization using telomeric probe in three Leptodactylus species (Leptodactylidae, Anura). Caryologia 57: 53-65.

Baldo, J. D. 2002. Estudios cromossómicos de las especies argentinas del género Leptodactylus Fitzinger 1826 (Amphibia, Anura). Unpublished Ph.D. Thesis. Universidad Nacional de Misiones, Argentina.

Barbieri, F. D. 1950. Observaciones sobre los cromosomas y espermatozoides en algunos batracios del genero Leptodactylus. Acta Zoologica Lilloana IX: 455-463.

Barrio, A. 1973. Leptodactylus geminus, una nueva especie del grupo fuscus (Anura, Leptodactylidae). Physis 32: 199-206.

Beçak, M. L. 1968. Chromosomal analysis of eighteen species of Anura. Caryologia 21: 191-208.

Beçak, M. L., L. Denaro and W. Beçak. 1970. Polyploidy and mechanisms of karyotypic diversification in Amphibia. Cytogenetics 9: 225-238.

Bianchi, N. O. and J. O. Molina. 1967. DNA replication patterns in somatic chromosomes of Leptodactylus ocellatus (Amphibia, Anura). Chromosoma 22: 391400.

Bianchi, N. O., M. S. Bianchi and L. Vidal-Rioja. 1973. Heterochromatin late replication and secondary constrictions in the chromosome complement of Leptodactylus ocellatus. Caryologia 26: 397-403.

Bogart, J. P. 1967. Chromosomes of the South American amphibians family Ceratophrydae with a reconsideration of the taxonomic status of Odontophrynus americanus. Canadian Journal of Genetics and Cytology 9: 531-542.

Bogart, J. P. 1970. Los cromosomas de anfibios anuros del genero Eleutherodactylus. Acta IV Congresso Latinoamericano de Zoologia 1: 65-78.

Bogart, J. P. 1973a. Evolution of anuran karyotypes. Pp. 337-349 in J. L. (ed.), Evolutionary Biology of the Anurans. Columbia, University of Missouri Press.

Bogart, J. P. 1973b. Method for obtaining chromosomes. Caldasia XI: 29-40.

Bogart, J. P. 1974. A karyosystematic study of frogs in the genus Leptodactylus (Anura: Leptodactylidae). Copeia 1974: 728-737. 
Brum-Zorilla, N. and F. A. Saez. 1968. Chromosomes of Leptodactylidae (Amphibia Anura). Experientia 24: 969.

De Lucca, E. J., J. Jim and F. Foresti. 1974. Chromosomal studies in twelve species of Leptodactylidae and one Brachycephalidae. Caryologia 27: 183-192.

de Sá, R. O., W. R. Heyer and A. Camargo. 2005. A phylogenetic analysis of Vanzolinius Heyer, 1974 (Amphibia, Anura, Leptodactylidae): Taxonomic and life history implications. Arquivos do Museu Nacional do Rio de Janeiro 63: 707-726.

Denaro, L. 1972. Karyotypes of Leptodactilydae frogs. Journal of Herpetology 6: 71-74.

Foote, D. L., J. E. Wiley, M. L. Little, and J. Meyne. 1991. Ribosomal RNA gene site polymorphism in Bufo terrestris. Cytogenetics and Cell Genetics 57: 196199.

Frost, D. R. 2004. Amphibian Species of the World: an Online Reference. Version 3.0. URL: http:// research.amnh.org/herpetology/amphibia/index.html. American Museum of Natural History, New York, USA. Captured on 22 August 2004.

Frost, D. R., T. Grant, J. Faivovich, R. H. Bain, A. Haas, C. F. B. Haddad, R. O. de Sá, A. Channing, M. Wilkinson, S. C. Donnelan, C. J. Raxworthy, J. A. Campbell, B. L. Blotto, P. Moler, R. C. Drewes, R. A. Nussbaum, J. D. Lynch, D. M. Green, and W. C. Wheeler. 2006. The amphibian tree of life. Bulletin of the American Museum of Natural History 297: 1-370.

Grant, T., D. R. Frost, J. P. Caldwell, R. Gagliardo, C. F. B. Haddad, P. J. R. Kok, D. B. Means, B. P. Noonan, W. E. Schargel, and W. C. Wheller. 2006. Phylogenetic systematics of dart-poison frogs and their relatives (Amphibia: Athesphatanura: Dendrobatidae). Bulletin of the American Museum of Natural History 299: 1262.

Heyer, R. 1969. The adaptive ecology of the species groups of the genus Leptodactylus (Amphibia, Leptodactylidae). Evolution 23: 421-428.

Heyer, W. R. 1972. The status of Leptodactylus pumilio Boulenger (Amphibia, Leptodactylidae) and the description of a new species of Leptodactylus from Ecuador. Contributions in Science of the Natural History Museum of Los Angeles County 231: 1-8.

Heyer, W. R. 1978. Systematics of fuscus group of the frog genus Leptodactylus (Amphibia, Leptodactylidae). Science Bulletin of the Natural History Museum of Los Angeles County 29: 1-85.

Heyer, W. R. and M. J. Diment. 1974. The karyotype of Vanzolinius discodactylus and comments on usefulness of karyotypes in determining relationships in the Leptodactylus-complex (Amphibia, Leptodactylidae). Proceedings of the Biological Society of Washington 87: 327-336.
Heyer, W. R., R. de Sá, J. R. Mc Craine, and L. D. Wilson. 1996. Leptodactylus silvanimbus (Amphibia: Anura: Leptodactylidae): natural history notes, advertisement call, and relationships. Herpetological Natural History 4: 169-174.

Heyer, W. R., R. de Sá and S. Muller. 2002. Leptodactylus silvanimbus. Catalogue of American Amphibians and Reptiles 743: 1-3.

Heyer, W. R., R. O. de Sá and S. Muller. 2005. The enigmatic distribution of the Honduran endemic Leptodactylus silvanimbus (Amphibia: Anura: Leptodactylidae). Pp 81-101 in M. A. Donnelly, C. Guyer and M. H. Wake (eds.), Ecology and Evolution in the Tropics: a herpetological perspective. Chicago, University of Chicago Press.

Howell, W. M. and D. A. Black. 1980. Controlled silver staining of nucleolus organizer regions with a protective colloidal developer: a 1-step method. Experientia 36: 1014-1015.

Kaiser, H., C. Mais, F. Bolaños, and C. Steinlein. 1996. Chromosomal investigation of three Costa Rican frogs from the 30-chromosome radiation of Hyla with description of a unique geographic variation in the nucleolus organizer regions. Genetica 98: 95-102.

Kasahara, S., A. P. Z. Silva and S. L. Gruber. 1998. Use of lymphocyte cultures for BrdU replication banding patterns in anuran species (Amphibia). Genetics and Molecular Biology 21: 471-476.

King, M. 1990. Amphibia in B. John and C. Gwent (eds.), Animal Cytogenetics. Volume 4. Chordata 2. Berlin, Gebrüeder Borntraeger.

Kuramoto, M. 1990. A list of chromosome numbers of anuran amphibians. Bulletin of Fukuoka University of Education 39: 83-127.

Larson, P. M. and R. de Sá. 1998. Chondrocranial morphology of Leptodactylus larvae (Leptodactylidae: Leptodactylinae): its utility in phylogenetic reconstruction. Journal of Morphology 238: 287-305.

León, P. E. 1970. Report of the chromosome numbers of some Costa Rican anurans. Revista de Biologia Tropical 17: 119-124.

Lourenço, L. B., P. C. A. Garcia and S. M. Recco-Pimentel. 2000. Cytogenetics of two species of Paratelmatobius (Anura: Leptodactylidae), with phylogenetic comments. Hereditas 133: 201-209.

Lourenço, L. B., P. C. A. Garcia and S. M. Recco-Pimentel. 2001. A cytogenetic and molecular analysis of the genera Paratelmatobius and Scythrophrys (Anura, Leptodactylidae), with emphasis on the nucleolar organizer region (NOR). Chromosome Research 9: 71.

Lourenço, L. B., P. C. A. Garcia and S. M. Recco-Pimentel. 2003. Cytogenetics of a new species of Paratelmatobius cardosoi group (Anura: Leptodactylidae), with 
the description of an apparent case of pericentromeric inversion. Amphibia-Reptilia 24: 47-55.

Lourenço, L. B., S. M. Recco-Pimentel and A. J. Cardoso. 1998. Polymorphism of the nucleolus organizer regions (NORs) in Physalaemus petersi (Amphibia, Anura, Leptodactylidae) detected by silver staining and fluorescence in situ hybridization. Chromosome Research 6: 621-628.

Mc Craine, J. R., L. D. Wilson and K. L. Williams. 1986. The tadpole of Leptodactylus silvanimbus, with coments on the relationships of the species. Journal of Herpetology 20: 560-562.

Miura, I. 1994. Sex chromosome differentiation in the Japanese brown frog, Rana japonica. II. Sex-linkage analyses of the nucleolar organizer regions in chromosome no. 4 of the Hiroshima and Saeki populations. Zoological Science 11: 807-815.

Morescalchi, A. 1970. Some trends of karyological evolution in the anura. Acta do IV Congresso Latino de Zoologia 1: 159-166.

Morescalchi, A. and G. Gargiulo. 1968. Su alcune relazione cariologiche del genere Bufo (Amphibia, Salientia). Rendiconto dell'Accademia delle Scienze Fisiche e Matematiche 35: 117-120.

Morescalchi, A., G. Gargiulo and E. Olmo. 1968. Note citotassonomiche sui Leptodactylidae (Amphibia, Salientia). Bollettino di Zoologia 35: 333-334.

Saez, F. A. and N. Brum. 1960. Chromosomes of South American amphibians. Nature 185: 945.

Savage, J. M. and J. E. De Weese. 1979. A new species of leptodactylid frog, genus Eleutherodactylus, from Cordillera de Talamanca, Costa Rica. Bulletin of the Southern California Academy of Sciences 78: 107-115.
Schmid, M. 1978. Chromosome banding in Amphibia I: Constitutive heterochromatin and nucleolus organizer regions in Bufo and Hyla. Chromosoma 66: 361-388.

Schmid, M., W. Feichtinger, R. Weimwer, C. Mais, F. Bolaños, and P. Léon. 1995. Chromosome banding in Amphibia. XXI. Inversion polymorphism and multiple nucleolus organizer regions in Agalychnis callidryas (Anura, Hylidae). Cytogenetics and Cell Genetics 69: 18-26.

Silva, A. P. Z., C. F. B. Haddad and S. Kasahara. 1999. Nucleolus organizer regions in Physalaemus cuvieri (Anura, Leptodactylidae), with evidence of a unique case of Ag-NOR variability. Hereditas 131: 135-141.

Silva, A. P. Z., C. F. B. Haddad and S. Kasahara. 2000. Chromosomal studies on five species of the genus Leptodactylus Fitzinger, 1826 (Amphibia, Anura) using differential staining. Cytobios 103: 25-38.

Silva, A. P. Z., P. C. A. Garcia, V. G. Martins, M. Bacci, and S. Kasahara 2004. Chromosomal and molecular analyses of Leptodactylus gracilis gracilis, L. gracilis delattini and L. plaumanni (Anura, Leptodactylidae): taxonomic implications. Amphibia-Reptilia 25: 185196.

Silva, A. P. Z., C. F. H. Haddad, G. G. Galassi, and S. Kasahara. 2006. Multiple nucleolus organizer in Leptodactylus mystacinus (Amphibia, Anura) and comments on its systematic position in the L. fuscus group based on cytogenetic and molecular analyses. Genetica 127: 35-44.

Willey, J. E., M. L. Little, M. A. Romano, D. A. Blount, and G. R. Cline. 1989. Polymorphism in the location of the 18S and 28S rRNA genes on the chromosomes of the diploid-tetraploid tree frogs Hyla chrysoscelis and $H$. versicolor. Chromosoma 97: 481-487. 
Appendix I - Available information on the karyotypes of Leptodactylus

\begin{tabular}{|c|c|c|}
\hline Species & $2 n$ & Reference \\
\hline L. albilabris & 22 & Bogart 1974 \\
\hline L. bolivianus & 22 & León 1970; Heyer and Diment 1974 \\
\hline L. bufonius & 22 & $\begin{array}{l}\text { Barbieri 1950, Bogart 1967, 1974, Brum-Zorrilla and Saez } \\
\text { 1968, Heyer and Diment 1974, Baldo } 2002\end{array}$ \\
\hline L. chaquensis & 22 & $\begin{array}{l}\text { Barbieri 1950, Brum-Zorrilla and Saez 1968, Heyer and Diment } \\
\text { 1974, Baldo } 2002\end{array}$ \\
\hline L. elenae & 22 & Heyer 1978, Baldo 2002 \\
\hline L. fuscus & 22 & $\begin{array}{l}\text { Beçak et al. 1970, Bogart 1974, Heyer and Diment 1974, Silva } \\
\text { et al. 2000, Baldo } 2002\end{array}$ \\
\hline L. geminus & 22 & Barrio 1973 \\
\hline L. gracilis & 22 & $\begin{array}{l}\text { Denaro 1972, Barrio 1973, Bogart 1974, Baldo 2002, Silva et } \\
\text { al. 2004, present study }\end{array}$ \\
\hline L. insularum & 22 & Bogart 1974 \\
\hline L. knudseni & 22 & Heyer 1972, Amaro-Ghilardi et al. 2004 \\
\hline L. labialis & 22 & León 1970, Bogart 1974 \\
\hline L. labyrinthicus & & \\
\hline $\begin{array}{l}\text { (L. pentadactylus } \\
\text { labyrinthicus) }\end{array}$ & 22 & $\begin{array}{l}\text { Denaro 1972, Kasahara et al. 1998, Silva et al. 2000, Baldo } \\
\text { 2002, present study }\end{array}$ \\
\hline L. laticeps & 22 & Brum-Zorrilla and Saez 1968 \\
\hline $\begin{array}{l}\text { L. latinasus } \\
\text { (L. prognathus) }\end{array}$ & 22 & $\begin{array}{l}\text { Barbieri 1950, Brum-Zorrilla and Saez 1968, Bogart 1974, } \\
\text { Baldo } 2002\end{array}$ \\
\hline L. macrosternum & 22 & Present study \\
\hline L. melanonotus & 22 & Bogart 1967, 1974, Heyer and Diment 1974 \\
\hline L. mystaceus & 22 & Bogart 1974, Heyer and Diment 1974 \\
\hline L. mystacinus & 22 & Bogart 1974, Baldo 2002, Silva et al. 2006, present study \\
\hline L. natalensis & 22 & Bogart 1974 \\
\hline L. notoaktites & 22 & Silva et al. 2000 \\
\hline L. ocellatus & 22 & $\begin{array}{l}\text { Barbieri 1950, Saez and Brum 1960, Bianchi and Molina 1967, } \\
\text { Beçak 1968, Brum-Zorrilla and Saez 1968, Bianchi et al. 1973, } \\
\text { Bogart 1974, Kasahara et al. 1998, Silva et al. 2000, Baldo } \\
\text { 2002, Amaro-Ghilardi et al. 2004, present study }\end{array}$ \\
\hline L. pentadactylus & 22 & $\begin{array}{l}\text { Brum-Zorrilla and Saez 1968, Morescalchi and Gargiulo 1968, } \\
\text { Morescalchi et al. 1968, Morescalchi 1970, Bogart 1974, Heyer } \\
\text { and Diment 1974, Amaro-Ghilardi et al. } 2004\end{array}$ \\
\hline L. petersii & 22 & Present study \\
\hline L. plaumanni & 22 & Baldo 2002, Silva et al. 2004 \\
\hline L. podicipinus & 22 & $\begin{array}{l}\text { Denaro 1972, Bogart 1974, Savage and De Weese 1979, Silva } \\
\text { et al. 2000, Baldo } 2002\end{array}$ \\
\hline L. pustulatus & 22 & Present study \\
\hline L. rhodonotus & 22 & Bogart 1974 \\
\hline L. silvanimbus & 24 & Present study \\
\hline L. wagneri & 22 & Bogart 1974, Heyer and Diment 1974, Savage and De Weese 1979 \\
\hline
\end{tabular}


Appendix II - Specimens Studied

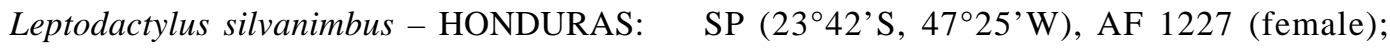

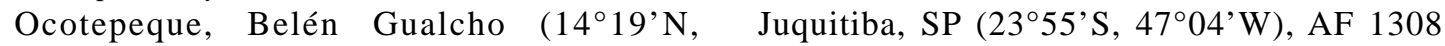
$88^{\circ} 47^{\prime} \mathrm{W}$ ), AF 95 (female).

Leptodactylus gracilis - BRAZIL: São

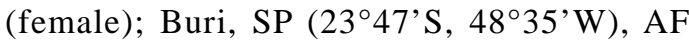
1374 (female).

Bernardo do Campo, SP (2341'S, 46³3’W), AF 1002, 1003 (males).

Leptodactylus petersii - BRAZIL: Igarapé Camaipi, AP (0010’S, 5153’W), AF 938 (female).

Leptodactylus mystacinus - BRAZIL: Aproveitamento Múltiplo de Manso, Chapada dos Guimarães, MT (15²7’S, 5544’W), AF 742 (male); Usina Hidrelétrica Guaporé, Jauru, MT (1520'S, 58 51'W), AF 1416 (female); Jam-

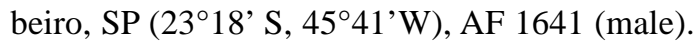
Leptodactylus labyrinthicus - BRAZIL:

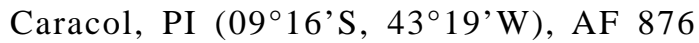
(male); Usina Hidrelétrica Guaporé, Jauru, MT (15²0's, 58, 51'W), AF 1417 (male).

Leptodactylus macrosternum - BRAZIL: Usina Hidrelétrica Lajeado, Palmas, TO (10¹2’s, $48^{\circ} 21^{\prime} \mathrm{W}$ ), AF 1266 (male); Palmeirante, TO (0751'S, 475' 'W), AF 1565 (female), AF 1568 (female).

Leptodactylus pustulatus - BRAZIL: Palmeirante, TO (0751'S, 4755’W), AF 1566 (male), AF 1567 (female). 